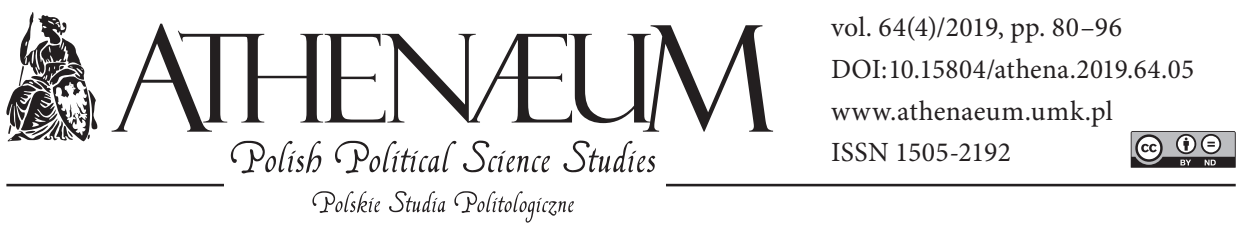

\title{
GEOPOLITICAL DETERMINANTS IN THE FOREIGN POLICY OF THE RUSSIAN FEDERATION
}

\author{
UWARUNKOWANIA GEOPOLITYCZNE W POLITYCE \\ ZAGRANICZNEJ FEDERACJI ROSYJSKIEJ
}

Michał Romańczuk* ๑

\begin{abstract}
International identity consists mainly of geographical, demographic, historical, political, military, economic, ideological, cultural and psychological factors. After the collapse of the USSR, Russia returned to tradition, not only in the sphere of political, social and philosophical ideas and ideologies, but also in the sphere of culture and religion. In the 1990s, the geopolitics revived. It became the basis for the development of the concept of foreign policy, the National Security Strategy and the Military Doctrine of the Russian Federation. The aim of the research is to analyze geopolitical perspectives in the identity of the Russian Federation and its impact on foreign policy concepts and sources of development of geopolitical concepts in Russia. The post-Soviet area is important for the security of the Russian Federation. Russia perceives armed conflicts in this area as an element of political 'game' in its strategic area.
\end{abstract}

Keywords: Russian Federation; geopolitics; political concepts; foreign policy; security strategy

\section{ABSTRAKT}

Na tożsamość międzynarodową składają się przede wszystkim czynniki: geograficzne, demograficzne, historyczne, ustrojowe, wojskowe, ekonomiczne, ideologiczne, kulturowe i psychologiczne. Po rozpadzie ZSRR powrócono w Rosji do tradycji, nie tylko na płaszczyźnie idei i ideologii politycznych, społecznych oraz filozoficznych, ale również w sferze kultury oraz religii. W latach 90 . XX wieku nastąpiło odrodzenie się geopolityki. Stała się ona podstawą do opracowania koncepcji polityki zagranicznej, strategii bezpieczeństwa narodowego oraz doktryny wojennej Federacji Rosyjskiej. Celem badań jest analiza ujęć geopolitycznych w tożsamości Federacji Rosyjskiej i ich wpływu na koncepcje w polityce zagranicznej oraz źródeł rozwoju koncepcji geopolitycznych w Rosji. Obszar postradziecki jest istotny dla bezpieczeństwa Federacji Rosyjskiej. Rosja postrzega konflikty zbrojne na tym obszarze jako element "gry" politycznej na jej strategicznym terenie.

Słowa kluczowe: Federacja Rosyjska; geopolityka; koncepcje polityczne; polityka zagraniczna; strategia bezpieczeństwa

\footnotetext{
* University of Szczecin, Faculty of Humanities.
} 


\section{INTRODUCTION}

The conclusion of the Belavezha Accords on December 8, 1991 by the presidents of Russia, Ukraine, and Belarus - Boris Yeltsin, Leonid Kravchuk, and Stanislav Shushkevich, respectively - sanctioned the collapse of the USSR ${ }^{1}$. The so-called post-Soviet area was also thereby created. After the collapse of the USSR and the transformation of its geopolitical environment, the authorities of the Russian Federation had to redefine Russia's identity and role, and its vision with regard to international relations.

The political activity of states is subject to constant transformations due to the dynamic changes that take place in the international environment. In this respect, attention should be paid to qualitative elements in the research, which are difficult to define, but helpful for grasping the driving forces behind the country's international strategy, the way that the country defines its own international position, and its stated roles in international relations (Bryc, 2012, p. 23).

The aim of this study is to analyse the role that geopolitical concepts have played in constructing the identity of the Russian Federation and influencing its foreign policy. Alongside the process of self-identification, states formulate and implement their international objectives, which reflect their shaped identity as, for example, a superpower, a partner, a client, a satellite, etc., and these in turn shape mutual interactions: hegemony, protection, integration, cooperation, rivalry, competition, and isolation (Bielen, 2006, p. 30). International identity is primarily determined by a variety of factors: geographical, demographic, historical, political, military, economic, ideological, cultural, and psychological.

After the collapse of the USSR, there was a return to tradition in Russia, not only in the sphere of political, social and philosophical ideas and ideologies, but also in the sphere of culture and religion. In the public debates of politicians and academics, the question often arises of the imperatives guiding of Russia's imperial identity. The factors determining Russian imperialism can be found in geopolitics, geography and historical heritage, which was shaped by civiliza-

1 The post-Soviet region currently consists of independent states such as: Ukraine, Belarus, Moldova, Georgia, Azerbaijan, Armenia, Kazakhstan, Uzbekistan, Kyrgyzstan, Tajikistan, and Turkmenistan. However, the three Baltic Republics, namely Lithuania, Latvia and Estonia, which joined NATO and the European Union, are not considered to be countries that belong to this area. Three regions can be distinguished in the post-Soviet area: the Southern Caucasus (Armenia, Azerbaijan, and Georgia), Central Asia (Kazakhstan, Kyrgyzstan, Turkmenistan, Uzbekistan, Tajikistan), and Eastern Europe (Ukraine, Belarus, and Moldova). 
tional and cultural expansion. Imperial actions can be defined as those aimed at extending the political, military, cultural and economic influence of states with a superpower status, or with aspirations to being such, to areas that do not belong to them. The Russian Federation is experiencing a mythologization of the idea of "imperium", which harks back to the times of Tsarist Russia and the USSR. This notion of empire is viewed positively, and many Russians feel they are the heirs of a great imperial tradition. Nostalgia for the empire has led to the emergence of a popular view in political and scientific circles in Russia, namely that the imperial path is the only way for modern Russia to develop.

\section{THE IMPACT OF GEOPOLITICAL CONCEPTS ON THE INTERNATIONAL IDENTITY OF THE RUSSIAN FEDERATION}

After the collapse of the USSR in the last decade of the $20^{\text {th }}$ century, the study of geopolitics re-emerged as an important and influential field of study in the Russian Federation. Geopolitics was used in attempts to explain the reasons for the loss of Russia's international position. For Russian political decision-makers it also became an inspiration and a basis for research carried out for the purpose of understanding the world and creating current and future international politics (Bassin \& Aksenow, 2006, pp. 99-100). In Russian scholarship there are three approaches to geopolitics: classical, recent, and the latest (contemporary). The first concerns classical geopolitical theories, the second focuses on economic issues - geoeconomics, while the third is moving away from geopolitical and economic determinants in favour of "geosophy", which analyses multidimensional space and takes into account cultural diversity in the world. This approach is also called: "the geopolitics of civilisation", "geoculture", "geophilosophy", "geopsychology", and "the computerisation of geopolitics". In its most up-to-date conception, Russian geopolitics is an interdisciplinary science that draws on the achievements of economics, geography, international relations, history, political science, national security, and psychology. It also employs the most modern technology and communication. Furthermore, this approach emphasises that power consists not only in material resources, but also in culture, language and religion. In order to undermine the power of a state, it is not essential to inflict material damage. The main target of the attack may be the culture and language of a given country. Hence the actions of the authorities of the Russian Federation, which challenge Western culture and civilisation, and proclaim the inevitable collapse 
of the United States of America with its liberal ideals, at the same time exalt and promote its Orthodox civilisation and the multipolar world order, which will consist of different centres, with different ideals and cultures. Due to its geographical location, Russian civilization, with its culture, philosophy, religion and traditions, will have a strong influence on the Eurasian territory, and thus contribute to the growing importance of the Russian Federation in the world in the coming decades (Legucka, 2013, p. 53).

The Russian people do not perceive the state in the same way that the peoples of Western Europe do. In Russia, there is a sense of loyalty to the state and its personification as Mother Russia, as well as loyalty to the authorities and the army, which are the most important components of the state. One can also draw attention to the origin of the term 'state' from the terms 'gosudar', 'gospodar', and 'gospad', which mean, respectively, 'master', 'the head of the family', and 'manager' (Eberhardt, 2006, p. 459). The sense of uniqueness which characterizes the perception of the Russian state among citizens and political elites is bound up with Orthodox messianism, imperialism, the "Russian spirit" and attachment to religion. This is related to the history and geographical location of the Russian Federation, which refers to the previously mentioned "geosophy". The policy of the Russian authorities over the centuries was characterised by strong territorial expansion, beginning in the $16^{\text {th }}$ century during the reign of Ivan the Terrible. European countries created their positions as superpowers through enlargement of their territories in overseas conquests. In contrast, Russia strengthened its position through the conquest of new territories on land and the creation of so-called "internal colonies" (Ząbek, 2010, p. 25). More emphasis was placed on territorial achievements than on the economic development of the country. These activities resulted in the Russian Federation's enduring and specific perception of territory. The territorial size of the Russian state is the main determinant of its position as a superpower in world politics. Therefore, it is not surprising that Vladimir Putin, President of the Russian Federation, speaking in his Annual Address to the Federal Assembly in 2005, said: "Above all, we should acknowledge that the collapse of the Soviet Union was a major geopolitical disaster of the century. As for the Russian nation, it became a genuine drama. Tens of millions of our co-citizens and compatriots found themselves outside Russian territory" (Annual Address to the Federal Assembly of the Russian Federation, 2005). Russian society felt humiliated by the disintegration of its great empire. After 1991, Russia lost 5 million $\mathrm{km} 2$ of territory and returned to the borders of the $16^{\text {th }}$ century, which amounted to retreating from the borders of Europe. Although the 
construction of a state of such vast territory had entailed that its citizens lacked personal freedom, it also caused a sense of national pride, as the metaphysical and sacral sphere was identified with territory.

Therefore, protecting its own territory against external threats is a key factor in Russian policy. It is the reason for Russia's passion for militarism and lies behind the creation of "buffer zones" around the state borders. Hence, for the Russian Federation the security of the post-Soviet area is a key determinant of its own development and security. It is primarily geopolitics that leads to the adoption of geographical determinism, which treats factors that result from the shape and character of the territory as absolute features - timeless and unchanging.

The power of the state is also defined through the prism of territory, and this has become another source for the development of geopolitical concepts in Russia. The geography and mythology of territory is bound up with the notion of there being a need for a strong, centralised state power which exercises control over this territory, and the army which is supposed to defend it. Power in Russia thus has a sacral dimension, possessing the legitimacy to use coercion and force, and to exact obedience and fidelity from society. However, the condition for this is that the exercise of power must be effective and bring benefits for the development of the country. It is an element of the social contract, in which individual goals must be subordinated to the interests of the nation as a whole. The Russian view is that the "national idea" thus understood will enable the resurrection of the imperial state (Bäcker, 2007, p. 19). The guiding concept behind Russian defence is that it is crucial to have a strong army. This is due to the country's geographical location, with long land borders and unstable neighbouring regions, which gives rise to a "besieged fortress" syndrome and the associated constant sense of threat from outside. Unlike the United States of America and the United Kingdom, which have better defensive capabilities thanks to their being surrounded by sea, in the Russian Federation the army does not only perform defensive functions: it also has the task of bonding the state and power. This is why the victory in the "Great Patriotic War" is celebrated with such pomp and fervour in Russia. In the times of the USSR, when there was an external enemy that threatened the existence of the state, propaganda justified the need to maintain a large army and to allocate significant financial resources to it. Hence, the Russian army undoubtedly suffered a huge loss of face during the First Chechen War of 1994-1996 (Grabowski, 2011, pp. 25-29). 


\section{SELECTED RUSSIAN GEOPOLITICAL CONCEPTS}

The first geopolitical concept to be described in writing is the idea of the "Three Romes" ${ }^{2}$, created by the monk Philotheus of Pskov at the end of the $15^{\text {th }}$ century. He expressed the view that following the fall of the ancient Roman Empire in 476, and the Byzantine Empire in 1453, Russia would become the new capital of Christianity faithful to Christ - the Orthodox centre of the world, or "Third Rome". There will be no fourth Rome. This messianic concept became the official ideology and explanation for the expansive policy of the Grand Duchy of Moscow, later the Russian Empire, and allowed for the "gathering" of all Russian lands under Moscow's rule. Later, this expansion was continued by Ivan the Terrible and other tsars of Russia (Furier, 2003, pp. 121-124).

The researchers Nicholas V. Riasanovsky and Mark D. Steinberg emphasize that the aim of Philotheus of Pskov was not to create an ideological basis for Russian foreign policy, but only to emphasize that the Orthodox faith was the true one (Riasanovsky \& Steinberg, 2009, p. 129). Paul Evdokimov, a Russian philosopher and theologian working in exile in France, was of the opinion that the idea of the Third Rome evoked above all the desire for holiness, which is necessary for defence and further existence of the Third Rome, until the return of Christ (Raźny, 2012, p. 14).

Like the idea of the Third Rome, the myth of "Holy Rus" has also functioned for the centuries. After the collapse of the USSR, the idea reappeared in nationalist circles in Russia at the turn of the $21^{\text {st }}$ century. Michał Soska indicates that it "expresses their desire to build a strong and powerful state on the international arena and to have a special historical mission" (Soska, 2009, p. 10), which refers to the belief in Russian messianism. Later on, this concept was developed by Lev Gumilyov, who defined Holy Rus as synonymous with the superethos of Eurasian civilization, in which the Orthodox Church primarily plays a political role, and only later a spiritual one. Kirill, the Patriarch of Moscow and all Rus', now appeals to the idea of "Holy Rus". The policy of the Russian Orthodox Church with regard to the post-Soviet Orthodox states corresponds to the foreign policy of the Russian Federation. After the unification of the Russian Orthodox Church with the

2 After the fall of Byzantium, Russia recognized itself as the continuation of the Byzantine tradition. The symbolic manifestation of the continuation was the marriage of the Grand Duke of Moscow Ivan III with Zoe (Sophia) Palaiologina, the niece of the last emperor of the Byzantine dynasty, Constantine XI Dragases Palaiologos. In addition, Russia took on the two-headed eagle in the coat of arms, the title of the tsar (emperor) and the Byzantine court ceremonies. 
Russian Orthodox Church outside Russia in 2007, the most important goal of the present patriarch Kirill was to obtain the greatest possible influence of the Russian Church in the post-Soviet countries, especially in Belarus, Ukraine, and Moldova (Ćwiek-Karpowicz, 2010).

Kirill is of the opinion that Holy Rus nowadays comprises Russia, Ukraine, and Belarus. This is why no autocephalous Orthodox churches can be established in Ukraine and Belarus ${ }^{3}$ - because Belarusians and Ukrainians should be under the authority of the Russian Orthodox Church. During his visit to Ukraine on the occasion of the $1020^{\text {th }}$ anniversary of the baptism of Kievan Rus, Kirill the Patriarch of Moscow and all Rus' stated in a public speech that: "Russia, Ukraine and Belarus are Holy Rus. Holy Rus is the ideal of love, goodness and truth. Holy Rus is beauty, Holy Rus is strength and we, together with you, are one Holy Rus (Matreńczyk, 2008, pp. 32-33). In another speech, Patriarch Kirill included Moldova in "Holy Rus" stating that Holy Rus is "a spiritual concept and not a political, linguistic or ethnic one, so it may include a non-Slavic country" (Svyateyshiy Patriarkh Kirill: Moldova - neot'yemlemaya chast' Svyatoy Rusi, 2010). The myth of "Holy Rus" has a religious character - the conviction that at first the people, and later the Russian nation, was called upon to serve God, which manifested itself in the very name of "Holy Rus". In this conception, the emphasis was placed on the role of religion as a factor shaping the geopolitics of a given community. In the process of self-identification, nations create their own identity and historical memory. The geopolitics of religion is therefore a way of thinking about space, territory and national identity (Zenderowski, 2011, pp. 30-32). An example of this is the Christmas greetings from Kirill the Patriarch of Moscow and all Rus', not only to Russians, but also to Belarusians, Ukrainians and Moldovans, emphasizing the unity of Orthodox civilization. In 2010, Patriarch Kirill stated that: "Moscow, Kiev, Minsk, Chisinau and Astana should become centres not only of particular states, but centres of a strong civilisation on behalf of which they are able to speak on an equal footing with other civilisations of the modern world" (Patriarkh Kirill prizyvayet strany russkogo mira stat' tsentrami yedinoy moshchnoy tsivilizatsii, 2010). Any attempt to create separate Ukrainian and Belarusian patriarchates is considered to be an artificial division of Eastern Slavs. Orthodox culture is also the basis of Russian nationalism with its imperial

3 On December 15, 2018, the Ukrainian Autocephalous Orthodox Church Canonical was established, which covers the jurisdiction of Ukraine. This decision met with strong negative reaction from the authorities of the Russian Federation and the Russian Orthodox Church. 
identity, which, however, should be treated separately from nationalist organisations (Wierzbicki, 2010, pp. 326-327).

One of the most eminent representatives of Russian geopolitics was undoubtedly Veniamin Semenov-Tian-Shansky. His own research interests focused mainly on the geography of Russia. He formulated a geopolitical concept which is an alternative to Halford Mackinder's theory. He argued that there is a relationship between broader historical and geographical generalizations, which is why geographical factors affect common history and political processes. According to his concept, the "critical" area can be distinguished on the globe, lying between the equator and the northern parallel of 45 degrees, where there are three great oceanic bays: the Mediterranean with the Black Sea, the Chinese (Southern and Eastern) Sea with the Japanese Sea, and Caribbean Sea with the Gulf of Mexico. Around these three strategic bays have developed the three largest civilizations and regional systems. He believed that this area, like the Halford Mackinder theory, plays the role of Heartland. Geopolitical competition takes place over the control of these three "ocean bays". On the other hand, the "ruler of the world" will be the civilization that manages to rule over these three seas simultaneously. In the concept of Veniamin Semenov-Tian-Shansky, one can observe the superiority of the theory of continental power. This theory assumes the primacy of the land by the sea. Countries that occupy the largest area of land will gain an advantage over others (Semenov-Tian-Shansky, 2008, pp. 144-160).

\section{EURASIANISM AND OCCIDENTALISM IN THE RUSSIAN FEDERATION'S APPROACH TO FOREIGN POLICY}

Since the $19^{\text {th }}$ century, Russia's identity as a civilization has been the subject of debates and disputes among the Russian intellectual elite - over whether Russia belongs to European or Asian civilisation, or whether it is a different geocultural entity that unites these two great civilisations (Duncan, 2005). For this reason, along with the newly gained freedom of expression and the abolition of censorship in the early 1990s, a debate took place on the fundamental issues of Russian national interests, identity and foreign policy. The conceptions of Russia's development after the collapse of the USSR appealed to the rebirth of the identity and self-identification of Russians. At that time two basic concepts emerged: Atlanticist (also called Occidentalism or Westernism), and Eurasian (Menkiszak, 2005, pp. 275-296). 
The Atlanticist concept was based on 19th-century Occidentalism, which proclaimed that Russia should accept the legacy of Western civilisation. The best option for the Russian Federation was said to be the abandonment of cultural isolation, to reject the patriarchal socio-political system associated with the country's Asian heritage and Orthodox faith, and to adopt the European system of norms, principles and values, based on rationalism and integration with Western civilisation (Bryc, 2012, pp. 30-31). The Russian Federation was to be connected with highly developed European countries and to cooperate closely with them, joining economic and political institutions. This cooperation was to have strengthened Russia's position and enabled it to shape the post-Cold War international order. It was also emphasized that the Russian Federation belongs to Western civilization in historical terms. The representatives of this trend were, among others: Dmitri Trenin, Vladimir Baranovski, Andrei Zagorski, Sergey Karaganov, and Alexey Arbatov. The implementation of this approach could be observed in the activities of the Minister of Foreign Affairs of the Russian Federation in 1991-1996, Andrei Kozyrev, and the Prime Minister in 1991-1992, Yegor Gaidar. However, attention should be paid to the deep asymmetry in the Atlanticist approach to relations with Western and post-Soviet states. The uneven involvement and focus on policy aspects with the so-called countries of the "near abroad" contributed to a loosening of trade, social and political ties with the region (Bielen, 2006, p. 67). Occidentalists proclaimed the need to reform the Russian Federation following the Western European model, to introduce a free market economy and democracy, which was to contribute to restoring the Russia's superpower status. In the scholarly literature, the period of the Atlanticists in the early 1990s is described as "romantic" (Cziomer \& Zyblikiewicz, 2006, p. 390).

The second significant idea in Russian foreign policy is that of Eurasianism. This idea refers to Eurasianist thought from the beginning of the $20^{\text {th }}$ century, as well as to Slavophilia, and is connected with the search for Russian identity. The idea of Eurasianism was created by the geographer Petr Savitsky. It posited that Russia's development is determined by the development of the state's territory. On the other hand, Lev Gumilyov formulated the thesis that Russia-Eurasia should be perceived as an autonomous and self-sufficient cultural type. Another representative of Eurasianism, Aleksandr Dugin, propounds the notion of geographical determinism. In his opinion, there are two hostile civilizations, shaped by geographical location, namely continental and island (oceanic) states. Aleksandr Dugin became involved in the implementation of his theories, which was reflected in the establishment of the pan-Russian Social-Political Move- 
ment "Eurasia" in 2001. It stood as a counterweight to liberal and Atlanticist ideology. According to this theory, the Russian Federation, due to its specific Eurasian location, combines the political, cultural and historical traditions of two continents - Europe and Asia - and this has resulted in its uniqueness and civilizational separateness from Europe (Dugin, 2007, pp. 331-336, see: Dugin, 1997). Theorists who are proponents of this idea also argue that Russia will never be just a European or Asian state. The Russian Federation has its own unique identity and national-state interests, which are geopolitically inextricably linked to the Eurasian territory. For this reason, Russia should follow its own "third way" of development, hence it is not possible for Russia to adopt the Atlanticist model of socio-political development. This is a clear reference to the idea of the "Third Rome". Eurasianism contains both messianic and imperialist concepts. The development of the Russian Federation depends above all on its "internal" power, connected with Orthodoxy and its own specific system of the state's functioning. The representatives of the Eurasian concept were first of all: Aleksandr Dugin, Lev Gumilyov, Natalya Narochnitskaya, Aleksey Mitrofanov, and Elgiz Pozdnyakov. Gennady Zyuganov, who is considered to be an extreme representative of this trend, should be identified as a political implementer of this concept. He published a manifesto entitled The Geography of Victory, in which he proclaimed the advent of the era of geopolitics. The idea is distinctly anti-Western. Zyuganov is in favour of seeking allies in order to counteract the hegemony of the USA. A similar rhetorical tone is employed by Vladimir Zhirinovsky, who creates and influences Russia's foreign policy through the Duma Committee on Geopolitics. He appeals to the imperial heritage of Tsarist Russia, as well as to Soviet times. The concept of Eurasianism asserts that the Russian Federation is a separate civilization, which should focus on expansion and the restoration of the control of influence and reintegration at the political, military and economic levels of the Eurasian territory (identified with the post-Soviet area). This entails involvement in armed conflicts in the area, assigning Russia the role of guarantor and protector, preventing post-Soviet states from strengthening cooperation and competition for influence in the area with other states, such as Turkey, Iran, China, and the USA (Trenin, 2001, pp. 50-65). It can be said that the geopolitics of the "near abroad" advocated in this idea has grown to the rank of an ideology, which is supported by nationalistic sentiments. The representatives of this concept indicate that it is possible to ally with some European countries in order to divide transatlantic unity, such as in the framework of cooperation with Germany and France. Eurasians were also 
in favour of increasing contacts with Asian countries. In addition, they have also expressed the view that India and China are essential pillars of the security system in Eurasia and a counterbalance to relations with the United States of America. Relations with the countries of the Middle and Far East were supposed to provide a balance to Eurocentrism and give Russia room for manoeuvre in international relations (Nizioł, 2004, pp. 159-169).

From the above considerations we can conclude that the mythologized conception of Eurasia was aligned with the geopolitical aspirations of the Russian Federation to integrate the post-Soviet area, and it thus became a priority in its foreign policy, as well as a factor that could bring about the restoration of national identity and pride. The proponents of Eurasianism also emphasized the confrontational aspect of the rivalry between the world's civilisation centres, in which the division into bad "Atlanticists" and good "Continentalists" was clear.

In addition to these two geopolitical concepts, the new so-called "third way" should also be mentioned. This "third way", navigated between East and West, is also known as "geopolitical realism". It was on this basis that the concept of "dynamic balance" in the Russian Federation's foreign policy was developed. It emerged during the rule of President Vladimir Putin, its aim being to strengthen, by all possible means, the Russian Federation's position in international relations. This approach avoids extreme nationalism, Eurasianism and Atlanticism, although it is moderately patriotic. From Eurasianism it draws the perception of Russia as a unique state, but rejects, inter alia, the inevitability of the confrontational relations with Western countries. According to this doctrine, the Russian Federation should be an important link in a new, multipolar world (Karaganov, 1994). This approach is supported by the current Russian political elites. It has become the foundation for shaping the foreign and security policy of the Russian Federation. Apart from Vladimir Putin, the representatives of this trend include Gleb Pavlovsky, Dmitri Trenin, Sergey Karaganov, Sergey Ivanov, and Igor Ivanov. This concept is also inscribed in the principle of "sovereign democracy", the creator of which is Vladislav Surkov, a close associate of Vladimir Putin. This principle asserts that state institutions should be strengthened by centralizing power, limiting the political role of regional elites and counteracting ethnic and regional separatism, which may destabilise the country. The state should play the main role in the economy and the organisation of social life. In this context, reference was made to paternalism, which was to become the foundation of the ideology of the new Russia (Bieleń, 2006, pp. 79-81). "Sovereign Democracy" 
holds that the Russian Federation cannot adopt the Western model of the political system because of its civilizational differences. The overriding aim is not, as in the democracies of Western countries, to protect equality and individual freedoms, but rather to ensure the security and sovereignty of the state. On the one hand, the main task should be to resist external pressures, mainly from the USA and Western European countries, which seek to limit Russian sovereignty, and, on the other hand, to counteract internal pressures in order to preserve Russia's own national identity and to continue to conduct an independent foreign policy, which should be differentiated and tailored to European and Asian countries (Wierzbicki, 2010, pp. 315-316).

It is said that the means by which Russia should pursue these objectives are primarily the modernisation of the state and its industry and internal reform, but while maintaining autonomy in political and economic decision-making, and without adopting Western cultural models and values. Nor should it give too much prominence to either its European or Eurasian side. The Russian Federation should use its own potential (mainly raw materials) and use pragmatism in politics to establish relations of "partnership" and "balance" between the European Union, the United States of America and the People's Republic of China. However, such cooperation must not be based on being subordinate to any of these countries. In the actions of President Vladimir Putin thus far, there is evidently a policy of balancing between East and West, flexibly adapting to the changing political situation. Priority has also been given to economic matters and the consolidation of large state-owned enterprises such as Gazprom, Rosneft, etc. Vladimir Putin is creating the image of himself as the defender of Russia's interests on the world stage so that Russia can regain the international position it deserves. In his rhetoric, the Russian President uses a kind of ideological-political syncretism, combining many programmatic concepts, striving to create a strong state with the status of a superpower (Bielen, 2006, pp. 83-87).

The doctrine of the "third way" in the foreign policy of the Russian Federation involves the implementation of four main objectives. The first is the restoration of Russia's position as a leader in the post-Soviet sphere, through the use of economic instruments in foreign policy. In the long term, the objective is to transform this area into an integrated region, along the lines of the European Union, under Russian leadership, which would become one of the "centres" of a multipolar world. The second goal is to use Russia's geopolitical advantages: nuclear weapons inherited after the collapse of the USSR, which are to be used as an element of deterrence; a permanent seat on the UN Security Council with 
the right of veto; a flourishing arms industry and arms trade; the deployment of military bases outside its borders; and the continued cooperation with traditional allies, e.g., Iran, Cuba, or Serbia. The third objective is cooperation with Western countries on various levels, while at the same time contesting the unilateralism of US policy. The fourth and final objective is to activate cooperation with the "emerging powers" in the world, i.e., India, China, and Brazil, in order to prevent Russia's foreign policy from being too Eurocentric and to promote multipolarity in the world. The aim is also to exploit the geopolitical communication opportunities between Europe and Asia. This would strengthen the Russian Federation's position as an intermediary in trade and services on the international market (Legucka, 2013, pp. 76-77).

Konstantin Sorokin, the main theoretician behind the concept of "dynamic equilibrium", argues that there are three geopolitical strategies for action: expansionist, subservient, and positional. Sorokin suggests that the Russian Federation is currently conceding to all the major powers. For this reason, Russia should adopt a positional strategy. In this case the main objective would be to keep as many countries in the post-Soviet area as possible within the orbit of Russian influence. This is to be achieved primarily through economic and military cooperation. President Vladimir Putin's speech at the Security Conference held in Munich on February 10, 2007 can be regarded as a political action that is aligned with this theory. At this time, he stated that the violent efforts of the US to solve international problems intensifies the efforts of many countries, including North Korea and Iran, to possess nuclear weapons in order to deter a possible attack (Pacuła, 2007). The Russian authorities are developing an imperial instinct, which is conducive to the creation of superpower tendencies, and thus to a return to the politics of power. The representatives of Eurasianism have been accused of neo-imperialism and the desire to rebuild Russia's power.

In addition to the concept of Atlanticism and Eurasianism, in modern Russia there is also the concept of "Island Russia", promoting moderate isolationism (see more: Sykulski, 2014, pp. 106-111). Due to the natural resources of Russia and the vastness of its territory, this trend has a long tradition in this country. Until the reign of Peter the Great, Russia was isolated from the rest of Europe. In line with the Russia-the Island concept, Russia is a unique world, separate from civilization and from Europe and Asia, not matching any political alliances. This concept is combined with the figure of Vadim Tsymbursky. The idea of "Island Russia" was created after the collapse of the USSR (see more: Potulski, 2010, pp. 204-205). Russia after 1991 lost its status of Russia-Eurasia, and became 
Russia in Asia, a Russian island in the heart of the land with foreign-minded youths (Chechens, Tatars). Russia ceased to be a superpower. Russia is a separate "ethnology platform". It is surrounded by other platforms: Romano-Germanic, Arabic-Iranian, Chinese, and Indian. "Island Russia" separates itself from other platforms by the Great Limitrof - the "geopolitical strait", or the territorial ring stretching from Central and Eastern Europe, through the Caucasus to Central Asia. Vadim Tsymbursky from the Great Limitrof secrets western territories - the strait. In his opinion, they coincide with the area of Central and Eastern Asia. In addition to "Island Russia" and large areas in the east, the existence of western territories - the straits - is a factor constituting the Russian geopolitical identity (Cymburski, 2014,pp. 70-79). Russia as a geopolitical object can be described by means of three features. First of all, it is an integral geopolitical niche of the Russian ethnos, lying to the east of the Roman-Germanic ethno-civilization platform. The second feature of Russia is the size of the difficult to develop space in the east. Finally, the third constitutive feature of Russia is the separation of the country in the west from Romano-Germanic Europe, the homeland of liberal civilization, a belt of peoples and territories adjacent to indigenous Europe, but not part of it. The insularity of Russia is also expressed in the basic types of wars that happened to it against states from the neighboring ethno-civilization platforms. Fighting with Russia or going on distant peripheries, without jeopardizing the vital centers of Russia, or the enemy, having managed to break into these centers, is cut off by "straits" from its back bases, surrounded and choked by foreign spaces. The concept of "Island Russia" has not become the dominant paradigm in Russian foreign policy. The reason for this is that the Russian geopolitical tradition is aimed at conducting global policy.

\section{CONCLUSION}

Geopolitics occupies a very important place in Russian politics. Reference is still made to the classical approaches, especially to concepts that give Russia a "privileged" position. Here, it is worth mentioning Halford John Mackinder's theory of "Heartland". Russian geopolitics demonstrates a sentiment for territory, which Russians view from a metaphysical perspective. Geopolitics is seen in a dualistic way, as both a blessing and a curse for society. After the collapse of the USSR, geopolitics was reborn in the Russian Federation with redoubled force. It became the basis for the development of the concept of foreign policy, the National Security 
Strategy and the Military Doctrine of the Russian Federation. In international politics, it was the basis for formulating together with other "players" - China, the USA, India, and the EU - a plan to implement the idea of multipolarity in international relations. In the Russian consciousness there is also a strong fear of being surrounded by enemies, hence the importance of the post-Soviet sphere for the security of the Russian Federation. Russia sees armed conflicts in this area as part of the political "game" in its strategic area. The involvement of states outside the region in these conflicts is perceived as interference in its internal affairs. The Russian Federation, together with the post-Soviet area, is still a strong geopolitical and geostrategic complex, which has an impact on world events. It should be pointed out that this influence is both creative and destructive. It is currently difficult to indicate which one is predominant. According to this geopolitical conception, Russia is clearly predestined to play a significant role in the post-Soviet area. Its main task is taken to be the reintegration of this area, with the core of this integration including Ukraine, Belarus, and Kazakhstan, in addition to the Russian Federation.

The Russian Federation strives to create its own cultural space, to give the Russian language the status of a means of global communication and to build its own cultural system, which would be resistant to external actions. Its aim is to create a strong international identity and emphasize the threat of the world's Westernization, thus reducing the influence of other cultures and creating a unipolar world dominated by the West. The Russian Federation is striving for a state of affairs in which civilizational spheres of influence would co-exist and the balance of power between civilizations in international relations would be maintained.

\section{REFERENCES:}

Annual Address to the Federal Assembly of the Russian Federation (2005, April 25). Retrieved from: http://en.kremlin.ru/events/president/transcripts/22931.

Bäcker, R. (2007). Rosyjskie myślenie polityczne za czasów prezydenta Putina. Toruń: Wydawnictwo Adam Marszałek.

Bassin, M., \& Aksenow, K.E. (2006). Mackinder and the Heartland Theory in Post-Soviet Geopolitical Discourse. Geopolitics, 11(1), 99-118. DOI: 10.1080/14650040500524129.

Bieleń, S. (2006). Tożsamość międzynarodowa Federacji Rosyjskiej. Warszawa: Oficyna Wydawnicza Aspra-Jr. 
Bryc, A. (2012). Wpływ geopolityki na tożsamość międzynarodową Polski i Rosji. In: A. Skrzypek, \& S. Bieleń (eds.). Geopolityka w stosunkach polsko-rosyjskich (pp. 23-43). Warszawa: Oficyna Wydawnicza ASPRA-JR.

Cymburski, W. (2014). Wyspa Rosja. Perspektywy rosyjskiej geopolityki. Pressje, 37.

Cziomer, E., \& Zyblikiewicz, L.W. (2006). Zarys współczesnych stosunków międzynarodowych. Warszawa: Wydawnictwo Naukowe PWN.

Ćwiek-Karpowicz, J. (2010). Cerkiew prawosławna w polityce zagranicznej Rosji. Biuletyn PISM, 110, 2281-2301.

Dugin, A. (1997). Osnovy geopolitiki: geopoliticheskoe budushchee Rossii. Moskva: Arktogeia.

Dugin, A. (2007). Geopolitika postmoderna. Vremena novykh imperiy. Ocherki geopolitiki XXI veka. Sankt-Petersburg: Amfora.

Duncan, P.S. (2005). Contemporary Russian Identity between East and West. The Historical Journal, 48(1), 277-294. Retrieved from: http://eprints.ucl.ac.uk/12931/1/12931. pdf.

Eberhardt, P. (2006). Prekursorzy i twórcy rosyjskiej geopolityki. Przegląd Geograficzny, $78(4), 455-472$.

Furier, A. (2003). Dekada Jelcyna. Uwarunkowania rosyjskich przemian społecznych $i$ politycznych 1991-2000. Szczecin: Wydawnictwo Naukowe Uniwersytetu Szczecińskiego.

Grabowski, T.W. (2011). Rosyjska siła. Siły Zbrojne i główne problemy polityki obronnej Federacji Rosyjskiej w latach 1991-2010. Częstochowa: Instytut Geopolityki.

Legucka, A. (2013). Geopolityczne uwarunkowania i konsekwencje konfliktów zbrojnych na obszarze poradzieckim. Warszawa: Wydawnictwo Difin.

Matreńczyk, A. (2008). Jednoczy nas matka ruskich miast. Przeglą Prawosławny, 8, 32-33.

Menkiszak, M. (2005). Rosyjskie wizje pozimnowojennego porządku międzynarodowego. In: R. Kuźniar (ed.). Porzadek międzynarodowy u progu XXI wieku (pp. 275-296). Warszawa: Wydawnictwo Uniwersytetu Warszawskiego.

Nizioł, M. (2004). Dylematy kulturowe międzynarodowej roli Rosji. Lublin: Wydawnictwo Uniwersytetu Marii Curie-Skłodowskiej.

Patriarkh Kirill prizyvayet strany russkogo mira stat' tsentrami yedinoy moshchnoy tsivilizatsii (2010, November 3). Retrieved from: http://www.interfax-religion. $\mathrm{ru} /$ ?act $=$ news\&div $=38063$.

Potulski, J. (2010). Współczesne kierunki rosyjskiej myśli geopolitycznej: między nauka, ideologicznym dyskursem a praktyką. Gdańsk: Wydawnictwo Uniwersytetu Gdańskiego.

Raźny, A. (2012). Pierwiastki chrześcijańskie w geopolityce nowego eurazjatyzmu. In: J. Machnik, \& I. Stawowy-Kawka (eds.). Prace Komisji Środkowoeuropejskiej PAU, 20(1), 7-19.

Riasanovsky, N.V., \& Steinberg M.D. (2009). Historia Rosji. Kraków: Wydawnictwo Uniwersytetu Jagiellońskiego. 
Semenov-Tian-Shansky, V.P. (2008). O mogushchestvennom territorial'nom vladenii primenitel'no k Rossii. Ocherk po politicheskoj geografii [About the Powerful Territorial Possession with Reference to Russia: Essay on Political Geography]. Prostranstvennaya ehkonomika, 2, 144-160.

Soska, M. (2009). Za Świętą Ruś. Współczesny nacjonalizm rosyjski - zarys ideologii. Warszawa: Wydawnictwo von Borowiecky.

Svyateyshiy Patriarkh Kirill: Moldova - neot'yemlemaya chast' Svyatoy Rusi (2010, August 21). Retrieved from: http://www.patriarchia.ru/db/text/1254808.html.

Sykulski, L. (2014). Geopolityka. Skrypt dla początkujacych. Częstochowa: Wydawnictwo Naukowe Grategia.

Trenin, D. (2001). Nenadezhnaya Strategiya [Unreliable Strategy]. Pro et Contra, 6(1-2), $50-65$.

Wierzbicki, A. (2010). Nacjonalizm cywilizacyjno-polityczny w etnopolityce Rosji. In: A. Dudek, \& R. Mazur (eds.). Rosja: między imperium a mocarstwem nowoczesnym. Toruń: Wydawnictwo Adam Marszałek.

Ząbek, M. (2010). Wstęp. Problemy tożsamościowe regionu Kaukazu. In: M. Ząbek (eds.). Dylematy kaukaskie. Problemy narodowościowe i migracje (pp. 17-38). Warszawa: Wydawnictwo DiG.

Zenderowski, R. (2011). Religia a tożsamość narodowa i nacjonalizm w Europie Srodkowo-Wschodniej. Między etnizacją religii a sakralizacja etosu (narodu). Wrocław: Wydawnictwo Uniwersytetu Wrocławskiego. 